\title{
Tourist's Perception of Safety in the Republic of Croatia in 2019
}

\author{
Rino Rivi Kolombatović, Rea Barbir, Petricija Knežić, Marko \\ Maretić, Katarina Stegić, Dolores Štefanac, Željana Bašić, \\ Ivana Kružić
}

This research has examined the attitudes and perceptions of tourists that visited the Republic of Croatia ( $\mathrm{RH}$ ) during the summer of 2019 about the perception of safety in $\mathrm{RH}$, especially on general security, as well as food safety, personal safety, epidemic safety, and natural disasters. Also, we have examined the confidence in Croatian services, such as the police, rescue services, medical emergency, etc. Almost all the safety components were above 4, which indicates that the tourists in Croatia feel safe and trust the services. This research could be a significant tool for improving the policies for attracting the tourists during and after the pandemic.

\section{KEY WORDS \\ $\sim$ Croatia, Tourists \\ $\sim$ Safety Perception \\ $\sim 2019$ \\ $\sim$ Food and water safety \\ $\sim$ Natural disasters safety \\ $\sim$ Emergency services \\ $\sim$ Public safety}

University of Split, University Department of Forensic Sciences, Croatia e-mail: zeljana.basic@unist.hr

doi: 10.7225/toms.v10.n02.019

This work is licensed under (cc) BY

Received on: 09.03.2021/Revised on: 21.07.2021/Accepted on: 23.08.2021/Published: 21.10.2021

\section{INTRODUCTION}

Tourism is one of the most important branches of the economy of the Republic of Croatia. At the Mediterranean, Croatia is among the most visited countries, and at the world level, it is important to emphasize that Croatia is one of the most desirable tourist destinations because of its historical, cultural, natural, and human features (Vuković, 2006). Also, Croatia has positioned herself on the 27 th place according to international competitiveness index, and it has occupied the 32nd place in the world economies with a positive growth (Travel\&Tourism, Competitiveness Report, 2019). Croatian tourism has shown high resilience to many factors, which is confirmed by higher growth rates than in the other competing countries (Government of the Republic of Croatia, 2013). For example, Croatia had a better change in score than the first countries on the list, Spain and France (Travel\&Tourism Competitiveness Report, 2019). Croatian tourism is supported by the Mediterranean climate, which is characterized by mild winters and warm summers, and in addition, Croatia is rich in natural and cultural heritage (Gluvačević, 2016; Uroević, 2012) . (Plitvička jezera National Park, cultural sites from the UNESCO, etc.) (Kapusta \&Wiluś, 2017).

In 2019, Croatia had an increase of $5 \%$ in tourist arrivals, almost 21 million of them, and 2.4\% more overnight stays were recorded (Ministry of Tourism of the Republic of Croatia, 2020). According to the eVisitor system, in 2019 the number of foreign tourist arrivals was $18,267,166$ (an increase of $4.4 \%$ ), while $2,424,455$ domestic tourist arrivals were recorded (an increase of $9.0 \%)$. In the same period, $94,812,813$ overnight stays of foreign tourists were realized (growth of $1.7 \%$ ), as well as $13,830,741$ overnight stays of domestic tourists (growth of 7.6\%) (Rihelj, 
2020). Growth in the number of arrivals and overnight stays is registered from distant markets of China, the USA and Canada, as well as Ukraine, Spain, Austria, Bosnia and Herzegovina, France, Italy, Hungary, Germany, Russia, Slovenia, Slovakia, Switzerland, the UK, and domestic market. Markets recording growth in arrivals with a slight decline in the number of overnight stays are Belgium, Denmark, Finland, and Poland. South Korea recorded a decline in arrivals with an increase in overnight stays. Markets that are declining in overnight stays and arrivals are the Czech Republic, Japan, the Netherlands, Norway and Sweden (Rihelj, 2020). The total turnover in 2019 (overnight stays) is dominated by the German market (19.5\%), followed by the domestic market (12.7\%), Slovenia (10.1\%) and Austria (7.1\%) (Rihelj, 2020).

Every year, the Ministry of Tourism of the Republic of Croatia prepares a strategic plan for the next two years. In that plan, they present goals and plans for the upcoming period, define projects and strategies. The following text describes part of the strategic plans for the period from 2018 to 2022 related to security in tourism. "The general goal of the strategic plan is to raise the competitiveness of Croatian tourism with the affirmation of Croatia as one of the leading international tourist destinations, i.e., the special goal implies the improvement of the tourist quality and contenst of the tourist product and the affirmation of Croatia on the international tourist market through effective promotion." (Ministry of Tourism, 2018).

As part of the special goal of improving the tourist quality and contents of the tourist product, the creation of prerequisites for a safe stay in our country is implied, because safety is one of the basic requirements for a successful conduct of tourist activity. Therefore, the Ministry of Tourism co-finances the costs of additional medical teams in destinations with a significantly increased number of tourists. Furthermore, it supports and cofinances training programs for organizers of tourist facilities, direct preventive action and other activities of the Croatian Mountain Rescue Service in order to ensure quality and safe implementation of special forms of tourism. It also participates in the Safe Tourist Season project. The international police cooperation has been implemented since 2006, with dozens of police officers from European Union countries and the region, as well as China and South Korea, who contribute towards a greater sense of security of their fellow citizens (Ministry of Tourism, 2018).

At the time of conducting this research no comprehensive study of the perception of safety of tourists in the Republic of Croatia has been published. Thus, we have conducted the research in the area of the city of Split. This research was conducted before the pandemic of the COVID-19 virus and could be extremely important after the end of the pandemic to create strategic frameworks and a return of tourists to Croatia.

The research of the tourist safety is extremely important for countries that want to maintain and improve their touristic offer.
This kind of survey gives an insight into potential problems and possibilities for improvement. Similar research in the world has already been conducted in numerous countries. For example, in Kuala Lumpur, where the issue of safety and security among women travellers was examined. What the researchers have highlighted as the most important safety issues are: personal safety and a sense of vulnerability and illness, accidents and political violence (Amir, Ismawi, 2015). According to a research conducted in Malaysia, including the citizens of India, China, Australia, France, and Indonesia, it was found that most tourists perceive earthquakes, tsunamis, SARS, terrorist attacks, and epidemics as risks and avoid travelling to the exposed countries. A similar study has been conducted in the Turkish province of Gaziantep, which found that respondents do not worry about terrorist attacks and food security, the reason for this being that most of them come from developed countries where such problems do not exist. Another study conducted in Turkey, has shown that natural disasters are the biggest risk for tourism, but also, on the one hand, they slow down the development of tourism and, on the other hand, attract people because of a sense of solidarity. They believe that the only solution for such situations is to develop management for dealing with crisis situations (Genç, 2018). In another survey, conducted in South Africa, tourism development is seen as an opportunity to overcome many socio-economic barriers that South Africa faces. The research focuses on and analyzes the poor perception of international tourists about personal safety in the period from 1997 to 1998 . The main reason for such perception is the high crime rate observed through six most important factors: public violence, rape, murder, and aggravated attacks, burglaries, robberies, and motor vehicle thefts, which were used to analyze the general pattern of crime (Ferreira, Harmse, 2012). Also, natural disasters affect the tourism significantly, which varies from one type of the disaster to another, for example the most negative impact have volcanic eruptions, whilst the folds and storms have the least impact (Rossello et.al., 2020). Not only that safety of the destination matters, but also the nationalities of the tourist, for example, one study has shown that the tourists coming from some countries (Israel, Ireland, USA) or a specific age groups are more likely to be sensation seeking tourists and that the marketing should also aim to the group of tourists depending on this type of the tourist offer (Pizam et al., 2004). Also, it seams that the nationality of the tourists also affects their readiness to visit destinations after major catastrophes, e.g., some nationalities are less worried when visiting such destinations (Kovačić et al., 2020). One study has shown the importance of the effect of the stress causing risk factors for the tourists and the necessity to adjust the marketing strategies according to analysis of such data (Lepp\&Gibson, 2003).

Considering all the stated above, the aim of this paper is to examine the tourist's perception of safety in Croatia, in the 
context of their sense of security in general, regarding the danger of a terrorist attack, food and water safety for consumption, flood and fire danger, considering the threat to fundamental human rights, awareness of culture and laws, given the level of trust in the police and health services and the risk of viral epidemics. The results of this research could be a good guidance for the improvement of Croatia as a tourist destination, as well as for creating the politics for the return of the tourists to Croatia after the COVID-19 pandemic ends.

\section{MATERIALS AND METHODS}

The research has been conducted using a survey questionnaire. The questionnaire consisted of basic demographic questions (gender, nationality, employment status, marital status, number of visits to the Republic of Croatia), while the second part of the questionnaire consisted of 22 questions related to a sense of security in Split / Croatia, and trust in the police and other institutions in the Republic of Croatia, food safety, etc., which had to be assessed with Likert scale (1) Strongly disagree; (2) Disagree; (3) Neither agree nor disagree; (4) Agree;
(5) Strongly agree). The questionnaire was been filled in by adult foreign nationals residing in the city of Split. The sample size was been determined using the sample size calculator available at https://www.surveysystem.com/sscalc.htm. The input variable was the number of visitors in the city of Split a year before the survey (2018), with a confidence interval set at $95 \%$. The data was analyzed in SPSS (version 18; SPSS Inc, Chicago, IL, USA), with the significance level set at $P \leq 0.05$.

The survey was conducted in the period from 2019-0615 to 2019-08-15. Foreign citizens who visited the city of Split were randomly interviewed. After the survey, a database with all collected samples was created, and the obtained data was statistically processed.

\section{RESULTS}

Out of the total number of respondents, 193 persons were female, and 161 persons were male.The average age of the female population was 31.79 years old, and the average age of the male population was 33.44 years old. The median age of the respondents was 32.72 years.

Table 1.

Average safety ratings of tourists, by gender.

\begin{tabular}{|c|c|c|c|}
\hline & Average rating - women (1-5) & Average rating - men (1-5) & $\mathrm{P}$ \\
\hline Personal safety influences my decision to travel. & $4.13(1-5)$ & $4.19(1-5)$ & 0.20 \\
\hline $\begin{array}{l}\text { I think that a terrorist attack in Croatia will most likely } \\
\text { not happen. }\end{array}$ & $3.96(1-5)$ & $4.05(1-5)$ & 0.16 \\
\hline I feel safe in the late hours in Croatia. & $4.13(1-5)$ & $4.06(2-5)$ & 0.21 \\
\hline $\begin{array}{l}\text { I think personal belongings in a hotel or private } \\
\text { accommodation are safe. }\end{array}$ & $4.1(2-5)$ & $4.19(1-5)$ & 0.15 \\
\hline I have confidence in the Croatian rescue services. & $4(2-5)$ & $4,11(1-5)$ & 0.02 \\
\hline I have confidence in the Croatian health services. & $3.76(1-5)$ & $3.82(1-5)$ & 0.10 \\
\hline I have confidence in the Croatian police service. & $3.89(1-5)$ & $4(2-5)$ & 0.07 \\
\hline
\end{tabular}

There were no statistically significant differences between males and females.

Considering the distribution of the participants by country, the number of countries represented by their participants was 40 , and on Figure 1 the countries represented by more than 10 participants are shown.

The total number of respondents by country with more than 10 respondents is 279 , which makes a total of $79 \%$. The remaining $21 \%$ or 73 respondents belong to nationalities with less than 10 respondents and were not considered when comparing scores based on the comparison of average scores of statements related to "Tourist Safety in the Republic of Croatia" by nationality base.

By dividing the nationalities by continents, those that will be compared, the following data was obtained (Russia in this case was assigned to the continent of Asia since $77 \%$ of Russia's territory is located in Asia). The results are shown in Figure 2.

In Table 2 the average rating of tourists by the continent is shown.

On the Figure 3 the work status of the respondents is shown. 


\section{Number of respondents by country}

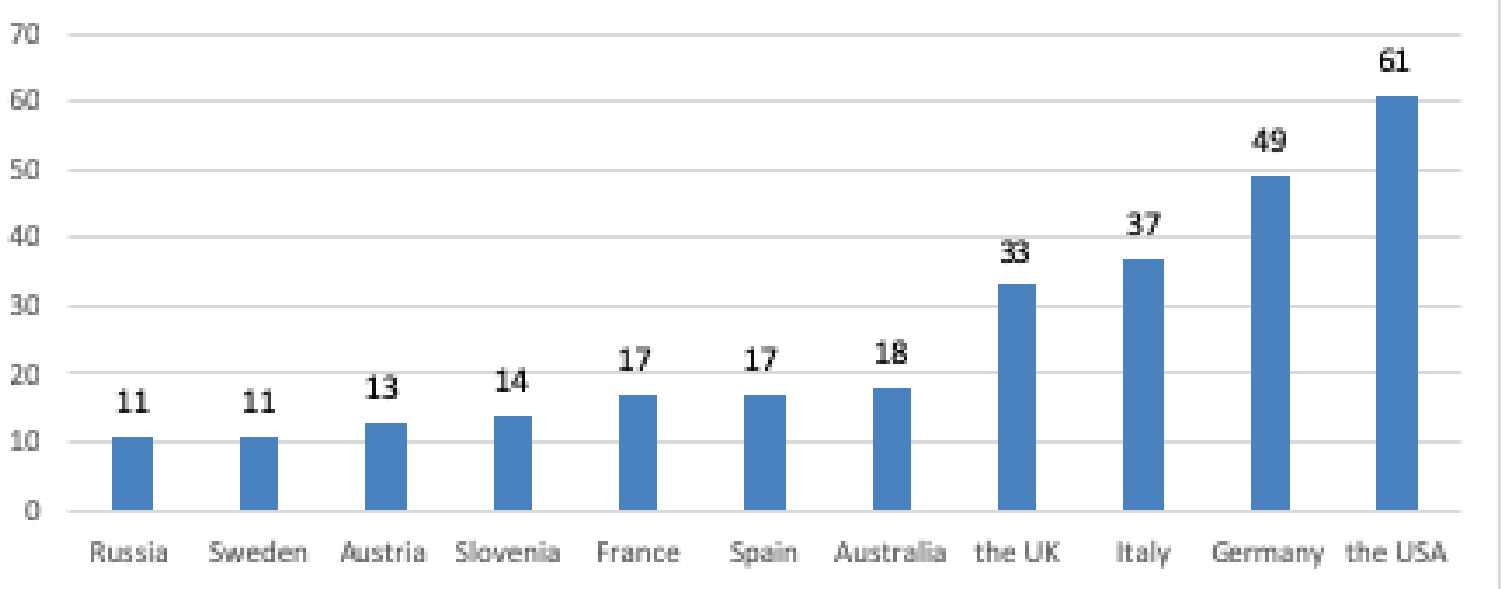

Figure 1.

Overview by countries with more than 10 respondents.

Table 2.

Average ratings of tourists by continents.

\begin{tabular}{|c|c|c|c|c|}
\hline & $\begin{array}{l}\text { Average rating - } \\
\text { residents of Europe } \\
(1-5)\end{array}$ & $\begin{array}{l}\text { Average rating - } \\
\text { residents of Asia } \\
(1-5)\end{array}$ & $\begin{array}{l}\text { Average rating - } \\
\text { residents of Australia } \\
(1-5)\end{array}$ & $\begin{array}{l}\text { Average rating - residents } \\
\text { of North America } \\
(1-5)\end{array}$ \\
\hline $\begin{array}{l}\text { I believe that Croatia is a safe } \\
\text { country. }\end{array}$ & $4.13(2-5)$ & $4.18(3-5)$ & $4(1-5)$ & $4.34(3-5)$ \\
\hline $\begin{array}{l}\text { In my case, Croats do not } \\
\text { discriminate against others on } \\
\text { national, racial, religious grounds, } \\
\text { etc. }\end{array}$ & $4.04(1-5)$ & $4.36(3-5)$ & $3.72(2-5)$ & $3.84(2-5)$ \\
\hline $\begin{array}{l}\text { I feel safe in the late hours in } \\
\text { Croatia. }\end{array}$ & $4.15(1-5)$ & $4.54(3-5)$ & $3.89(2-5)$ & $4.03(3-5)$ \\
\hline $\begin{array}{l}\text { I have confidence in the Croatian } \\
\text { rescue services in case of natural } \\
\text { disasters. }\end{array}$ & $4.19(3-5)$ & $4.27(3-5)$ & $3.5(2-5)$ & $4(2-5)$ \\
\hline $\begin{array}{l}\text { I am not afraid of a serious viral } \\
\text { epidemic in Croatia. }\end{array}$ & $4.1(1-5)$ & $4(3-5)$ & $3.89(2-5)$ & $3.80(1-5)$ \\
\hline $\begin{array}{l}\text { I had no unpleasant experiences } \\
\text { with the Croatian police. }\end{array}$ & $4.35(2-5)$ & $4.27(3-5)$ & $4.39(3-5)$ & $4.31(3-5)$ \\
\hline
\end{tabular}




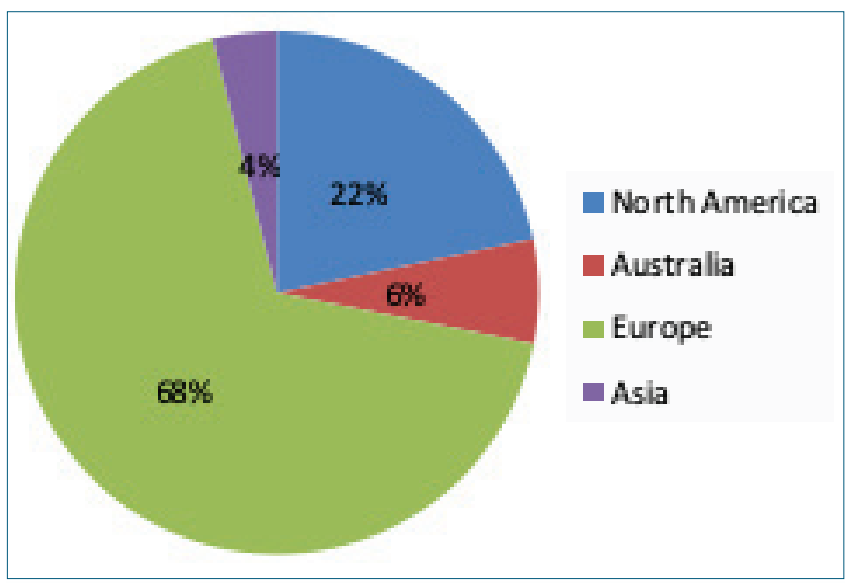

Figure 2.

Number of respondents by the continent.

The average students'score of the impact of personal safety when deciding on a trip is 3.73 , employed respondents 4.06 , pensioners' 3.9 and unemployed respondents' 3,4 . The majority of respondents stated that they were not discriminated against on the basis of nationality, religion or race in Croatia. Also, most of them stated that they considered Croatia a safe country and did not fear that they could be victims of kidnapping or some natural disaster. As for the trust in health services, there were no major discrepancies in responses. Out of a maximum of 5, the average score was 3.79. Students and employees had more confidence in the safety of their personal belongings in hotels or private accommodation, for students and employees the average was higher than 4, while for pensioners and the unemployed it was lower, 3.7.

Considering the relationship status of the participants, 206 respondents were in a relationship or married, the other 148 were single, i.e., they had no partners. In terms of the impact of personal safety on their travel decisions, the average score of single respondents was 3.91, while the average score of the married ones or those in a relationship was 3.95. They equally believed that the Republic of Croatia was a safe country. They shared the same opinion on the comparison of the Republic of Croatia with other EU members and believed that it was safer, with an average score of 3.6. Respondents who were married or in a relationship believed that Croats did not discriminate against others based on nationality, race, or religion. They shared the same opinion that there was little possibility for terrorist attacks in the Republic of Croatia and that they could be the victims of kidnapping. It is important to mention that singles felt less safe in the late hours in the Republic of Croatia. Both groups had the

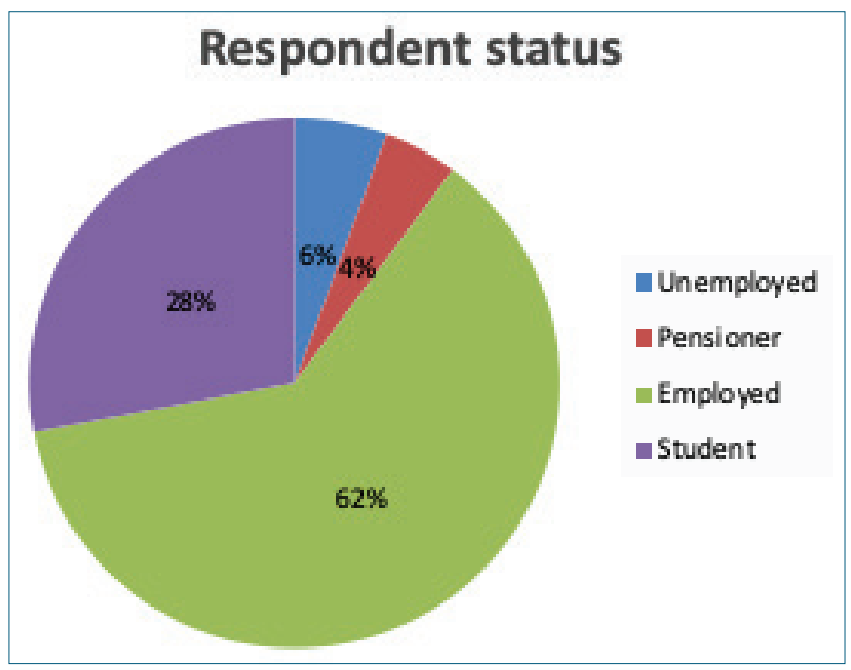

Figure 3.

Respondents by the work status.

same opinion on the water and food safety for consumption in the Republic of Croatia, which made the highest average score (4.33) in the entire questionnaire. The biggest difference between the participants that were not in a relationship or married and those who were was the inconvenience they had experienced with the Croatian police; the first ones trusted the Croatian police less than the people in a relationship, and their presence on the streets had no effect on their sense of safety.

Out of the total number of respondents, $66 \%$ had no children. The average scores of respondents with children and those without children differ greatly. Respondents with children agreed more with the fact that the Republic of Croatia was a safe country, with an average score of 4.14 , the respondents had an average score of 3.71. There was no difference in terms of the safety of the Republic of Croatia compared to other EU members. Respondents without children believed that Croatia was safer than the country they came from with an average score of 3.97, and the average score of respondents with children was 3.25. Respondents with children agreed more with the fact that it was necessary for the Croatian tourism to make a manual for tourists. Respondents without children believed more to have a small chance of a terrorist attack and to be victims of kidnapping in the Republic of Croatia, and to be safer on the streets in the late hours. The big difference in the average rating of trust in Croatian rescue services in case of natural disasters was that the respondents with children (4.2) believed more than the respondents without children (3.78). This difference is statistically significant $(P=$ 0.006). There was a small difference between the fear of serious 
viral epidemics in the Republic of Croatia, the respondents with children gave an average score of 4.13 , while the respondents without children gave 4.04. Distrust in the Croatian police was much higher among the respondents without children, with an average score of 3.61, while the respondents with children trusted the Croatian police more, with an average score of 4.15, and this difference is statistically significant $(P=0.0002)$.

Regarding the number of trips, half of the respondents stated that they travelled 2-3 times a year, 32\% travel once a year, and $18 \%$ more than three times a year. When asked about the impact of safety on the decision to travel, all respondents mostly shared the opinion, so the average score for all three groups was 3.93. Also, most of them considered Croatia a safe country and stated that they had not experienced discrimination based on nationality, religion, or race in Croatia. When asked whether they considered Croatia safer than other EU countries, an average score of 3.58 out of a possible 5 was obtained. Most respondents believed that food and water were safe for consumption, also expressing confidence in the Croatian emergency services and were not afraid of being a victim of kidnapping or natural disaster. Respondents stated that they felt safe during the night hours, so the average score was 4.08 .

Most of the respondents have visited more than five countries so far, 267 respondents to be precise, which made $75 \%$ of the total number of respondents. The average age of respondents who had visited less than five states was 29.31 years, and those who had visited more than five countries before visiting Croatia were, on the average, 33.84 years old. $73.91 \%$ of male respondents, and $75.39 \%$ of female respondents had visited more than five countries.

Table 3 shows a comparison of the respondents' opinions based on their travel experience.

Table 3.

Average scores of respondents based on their travel experience.

\begin{tabular}{|c|c|c|c|}
\hline & $\begin{array}{l}\text { Average rating given by } \\
\text { people who visited less than } \\
\text { five countries } \\
(1-5)\end{array}$ & $\begin{array}{l}\text { Average rating given by } \\
\text { people who visited more than } \\
\text { five countries } \\
(1-5)\end{array}$ & $\mathrm{P}$ \\
\hline Personal safety influences my decision to travel. & $3.91(2-5)$ & $3.94(1-5)$ & 0.39 \\
\hline I believe that Croatia is a safe country. & $4.18(3-5)$ & $4.15(1-5)$ & 0.35 \\
\hline $\begin{array}{l}\text { Before coming to Croatia, I was informed about } \\
\text { the way of life, culture, history, laws. }\end{array}$ & $3.64(1-5)$ & $3.71(1-5)$ & 0.28 \\
\hline I feel safe in the late hours in Croatia. & $4.19(2-5)$ & $4.05(1-5)$ & 0.07 \\
\hline $\begin{array}{l}\text { I think that Croatian food and water are safe for } \\
\text { consumption. }\end{array}$ & $4.29(2-5)$ & $4.34(2-5)$ & 0.30 \\
\hline $\begin{array}{l}\text { I am not afraid of a serious virus epidemic in } \\
\text { Croatia. }\end{array}$ & $3.93(1-5)$ & $3.93(1-5)$ & 0.49 \\
\hline I have confidence in the Croatian police service. & $3.95(2-5)$ & $3.95(1-5)$ & 0.48 \\
\hline $\begin{array}{l}\text { I had no unpleasant experiences with the } \\
\text { Croatian police. }\end{array}$ & $4.29(1-5)$ & $4.29(1-5)$ & 0.46 \\
\hline
\end{tabular}

As seen in Table 3, there were no statistically significant differences between the experienced and less experienced travellers. Out of the total number of respondents, $69 \%$ visited Croatia for the first time.
Table 4 shows the average ratings of respondents who visited Croatia for the first time (69\%) and those who have visited Croatia more than one time. 
Table 4

Average ratings of persons who have visited the Republic of Croatia for the first time and more than once.

Average ratings given by persons who are in the Republic of Croatia for the first time.

(1-5)

$4.18(1-5)$

I believe that Croatia is a safe country.

In my case, Croats do not discriminate against 3.97 (1-5) others on national, racial, religious grounds, etc.

\begin{tabular}{llll}
\hline I feel safe in the late hours in Croatia. & $4.1(1-5)$ & $4.05(1-5)$ & 0.31 \\
\hline $\begin{array}{l}\text { I have confidence in the Croatian rescue } \\
\text { services in case of natural disasters. }\end{array}$ & $4.07(2-5)$ & $4.1(1-5)$ & 0.25 \\
\hline $\begin{array}{l}\text { I am not afraid of a serious viral epidemic in } \\
\text { Croatia. }\end{array}$ & $4(1-5)$ & $3.77(1-5)$ & 0.02 \\
$\begin{array}{l}\text { I had no unpleasant experiences with the } \\
\text { Croatian police. }\end{array}$ & $4.25(1-5)$ & $4.42(2-5)$ & 0.04 \\
\hline
\end{tabular}

Average grade given by persons

P who visited the Republic of Croatia more than once. (1-5)
Statistically significant difference was observed between the two groups in the question of discriminating against others on national, racial, religious grounds, with more positive answers from those being in Croatia for the first time.

\section{DISCUSSION AND CONCLUSIONS}

The results of the research on a total of 354 respondents has shown that tourists in the Republic of Croatia feel safe. Namely, the overall average safety rating was 4.16 . The study involved 193 females and 161 males. Analyzing the answers given by females or males, no major discrepancies were observed in the given ratings. Analyzing the answers in terms of the age of the respondents, we have concluded that there is no significant difference, to most of the questions the same answers were given by the respondents of all age groups. No statistically significant differences were found in their responses.

Every country has its own cultural characteristics and nowhere is it the same. This fact can be best explained by foreigners visiting the Republic of Croatia. Thus, for example, those who have visited more than five countries so far, consider Croatia a safe country and there are no statistically significant differences between respondents who have visited less than five and more than five countries. They share the same opinion when it comes to trust in the Croatian police and fear of a serious viral epidemic in Croatia. They also feel equally safe in the late hours in Croatia and with a high score confirm the absence of unpleasant experiences with the Croatian police.

For example, people in North America think that Croatia is a safe country with an average score of 4.34 , while Australians give the lowest average score of 4 . That Croatia is not a country of racial intolerance and discrimination is mostly thought by people in Asia, with an average score of 4.36, while Australians still give the lowest average grade of 3.72. Asians have the most trust in Croatian rescue services, with an average rating of 4.27, while residents of Australia, with the average rating of 3.5, have the least trust. As for the fear of a serious epidemic, the average on all the respondents, regardless the continent they are from, is almost the same and ranges from 3.8 to 4.1 , which shows that all residents agree the most and believe that there is no excessive fear of an epidemic. A high average score for the absence of unpleasant experience with Croatian police, from 4.27 to 4.35, shows that the participants from all the observed continents agree that they did not have any bad experiences with the Croatian police.

According to marital status, there are no statistically significant differences in average scores. They equally agree that Croatia is a safe country, and that Croatia is safer than other EU members. Analyzing the average scores of those in relationships and the single ones, those in a relationship agree more that they 
are less likely to be abduction victims, while single respondents gave a lower average score, which means they agree less with this statement. Also, single people had more unpleasant experiences with the Croatian police than those in a relationship, although the difference was not significant. According to the answers given, the highest average score is reflected in the safety of food and beverages in Croatia.

Respondents with children and those with no children show differences in scores. Respondents without children trust rescue services less in the event of a natural disaster, trust the Croatian police less, and feel less secure when they see the police on the street. Also, respondents without children do not agree that the cooperation of the Croatian police with foreign police is of great importance, and the lowest average grade is given for this statement. In terms of safety, respondents with children feel safer in the Republic of Croatia, but not as safe as they feel in the country they come from, and respondents with and without children share the same opinion: that Croatia is a safer country than other EU members.

Analyzing the answers of the respondents regarding their employment status, it can be concluded that employed persons and students decide more to travel, and unemployed persons and pensioners decide this to a lesser extent. Most respondents agreed that they did not experience discrimination based on nationality, religion, and race in Croatia. Also, most of them agreed that they considered Croatia a safe country and were not afraid that they could be victims of kidnapping or natural disaster. The only significant discrepancies in the answers are visible in the issue related to the safety of personal belongings in hotels or private accommodation, where students and employees gave significantly higher grades, i.e., they considered their personal belongings in private accommodation and hotels to be safe.

According to the number of trips, most respondents stated that they travelleed two or three times a year, followed by respondents who travel once a year, and the least of those who travel more than three times a year. All three groups of respondents agreed that the safety of the country affected their decision to travel. Also, most of them stated that they dd not feel discriminated against based on nationality, race, or religion in Croatia. They also gave high scores to questions about food and water safety for consumption and trusted in emergency services. They also state that they feel safe during the night and that most of them have not had an unpleasant experience with the Croatian police.

The period in which the survey was conducted (summer of 2019) will probably serve the best as an orientation about the post COVID pandemic tourism. The survey was conducted only half a year before the outbreak of the COVID pandemic that would, as we have seen, affect tourism, at least for several years. The pandemic 2020 has downgraded Croatia to 20 years ago. Croatia had $64.2 \%$ less arrivals and $55.3 \%$ less overnight stays
(Croatian Bureau of Statistics, 2021). Taking into consideration that Croatia had suffered losses in the tourist industry, in future, post-pandemic years, the authorities should be focused upon attracting even more tourists to compensate the losses. Our survey could be of great importance for strategic planning, as it shows pre-pandemic tourists' attitudes about safety. Improvements in the areas that have been recognized as most worrying and a marketing towards the less prone populations or demographic groups could be one of the strategic goals of Croatian tourism marketing. This study could also direct different marketing strategies in different countries, focusing more upon the issues that worry specific subgroups or populations. Croatia should focus on her strengths and improve her flaws, thereby directly influencing not only the "subjective" perception of the tourists but also the overall quality of the tourist offer in the field of safety.

Overall, this research has shown that Croatia is perceived as a safe tourist destination, and as highlighted by the survey participants, their major confidence lies in the safety of food and water, which could and should be highlighted in the promotion of Croatian as tourist destination. It should be noted that the research was done before the coronavirus pandemic and that now, probably, the results would be significantly different in the perception of the pandemic safety. Given that tourism is a major source of increased human mobility, it is one of the most important factors in spreading of coronavirus, especially in Europe. It should be noted that many countries have suffered heavy losses in the field of economy, as well as the health system, and that the population will not be primarily oriented towards tourism and tourist travel. Although many things will change after this pandemic, this research in the future could be used to study the changes that have occurred and, according to tourists, to discover our strengths and weaknesses, to introduce changes to be better and more successful, and consequently become a more attractive destination for tourists.

\section{REFERENCES}

Amir, A.F., Ismail, M.N.I. \& See, T.P., 2015. Sustainable Tourist Environment: Perception of International Women Travelers on Safety and Security in Kuala Lumpur. Procedia - Social and Behavioral Sciences, 168, pp. 123-133. Available at: http://dx.doi.org/10.1016/j.sbspro.2014.10.218.

Croatian Bureau of Statistics, 2020. Tourist arrivals and nights in commercial accommodation establishments. Available at: https://www.dzs.hr/Eng/Covid-19/ tourism-arrivals_and_nights_2020.html.

Gluvačević, D., 2016. The power of cultural heritage in tourism-example of the city of Zadar (Croatia). International journal of scientific management and tourism, 2(1), pp. 3-24.

Ferreira, S.L.A. \& Harmse, A.C., 2000. Crime and Tourism in South Africa: International Tourists Perception and Risk. South African Geographical Journal, 82(2), pp.80-85. Available at:

http://dx.doi.org/10.1080/03736245.2000.9713696. 
Genç, R., 2018. Catastrophe of Environment: The Impact of Natural Disasters on Tourism Industry. Journal of Tourism \& Adventure, 1(1), pp.86-94. Available at: http://dx.doi.org/10.3126/jota.v1i1.22753.

Kapusta, A. \& Wiluś, R., 2017. Geography of Tourism in Croatia. The Geography of Tourism of Central and Eastern European Countries, pp.109-147. Available at: http://dx.doi.org/10.1007/978-3-319-42205-3_4.

Kovačić, S. et al., 2020. What are the Factors affecting Tourist Behavior based on the Perception of Risk? Romanian and Serbian Tourists' Perspective in the Aftermath of the recent Floods and Wildfires in Greece. Sustainability, 12(16), p.6310. Available at: http://dx.doi.org/10.3390/su12166310.

Lepp, A. \& Gibson, H., 2003. Tourist roles, perceived risk and international tourism. Annals of Tourism Research, 30(3), pp.606-624. Available at:

http://dx.doi.org/10.1016/s0160-7383(03)00024-0.

Pizam, A. et al., 2004. The Relationship between Risk-Taking, Sensation-Seeking, and the Tourist Behavior of Young Adults: A Cross-Cultural Study. Journal of Travel Research, 42(3), pp.251-260. Available at: http://dx.doi.org/10.1177/0047287503258837.

Rihelj, G., 2020. U 2019. godini ostvareno 21 milijuna dolazaka i 108,6 milijuna noćenja. Available at: https://hrturizam.hr/resume-2019-godine-ostvareno-21milijuna-dolazaka-i-1086-milijuna-nocenja/, accessed on: 15. Feb 2020.
RH, Ministarstvo turizma, 2020. Available at: https://mint.gov.hr/vijesti/u-2019godini-21-milijun-turista-5-posto-vise-nego-u-2018-nocenja-2-4-posto-vise/20762, accessed on: 15 Jan 2020.

RH, Ministarstvo turizma, 2018. Strateški plan Ministarstva turizma za razdoblje 2019.-2021. Available at: https://mint.gov.hr/UserDocslmages/AA_2018_ cdokumenti/180403_strateski-p_mint.pdf, accessed on: 20. Feb 2020.

Rosselló, J., Becken, S. \& Santana-Gallego, M., 2020. The effects of natural disasters on international tourism: A global analysis. Tourism Management, 79, p.104080. Available at:

http://dx.doi.org/10.1016/j.tourman.2020.104080.

Urosevic, N., 2012. Cultural identity and cultural tourism: Between the local and the global (a case study of Pula, Croatia). Singidunum Journal of Applied Sciences, 9(1), pp.67-76. Available at:

http://dx.doi.org/10.5937/sjas1201067u.

$\mathrm{RH}$, Vlada, 2020. Strategija razvoja turizma RH do 2020. godine. Available at: https:// narodne-novine.nn.hr/clanci/sluzbeni/2013 05_55_1119.html/, accessed on: 15 . Jan 2020 .

Vuković, I., 2006. Suvremeni trendovi u razvoju turizma u EU i implikacije na Hrvatsku, pp. 35-55.

World economic forum, 2019. The Travel \& Tourism Competitiveness Report 2019. Travel and Tourism at a Tipping Point. Geneva. 